\title{
Investigating the Use of Learning Objects for Secondary School Mathematics
}

\author{
Robin Kay and Liesel Knaack \\ University of Ontario Institute of Technology, Canada
}

\author{
robin.kay@uoit.ca; liesel.knaack@uoit.ca
}

\begin{abstract}
Research on the impact of learning objects in secondary school mathematics classes is limited. To date, only two investigations have been reported in this area. The current study presents a comprehensive analysis of the use and effect of learning objects in secondary school mathematics classrooms. Teacher and student attitudes, as well as student performance, were used to assess the impact of learning objects for 298 students and 11 teachers in 20 different classrooms. Teacher att it udes were positive with respect to quality, engagement, and learning value of learning objects. Student att itudes, on the other hand, varied markedly. Overall, student performance increased significantly after using learning objects, although gains observed were small and highly variable. Student performance was significantly related to the intended purpose of a lesson and teaching strat egy selected. Planning time, using learning objects for review or to introduce new concepts, and supplying guided handouts improved student performance. It is reasonable to conclude that mathematics-based learning objects are viable teaching tools when used with the appropriate goals and strategies.
\end{abstract}

Keywords: mathematics, use, evaluate, secondary school, leaming object

\section{Introduction}

Learning objects are operationally defined in this study as interactive web-based tools that support the learning of specific concepts by enhancing, amplifying, and/or guiding the cognitive processes of learners. While the design, development, reuse, and accessibility of learning objects has been examined in some detail for almost 10 years (Kay \& Knaack, 2007a, 2007b), research on the effectiveness and usefulness of leaming objects is limited, particularly in the area of secondary school mathematics (Kay \& Knaack, 2007c; Lopez-Morteo \& Lopez, 2007).

It is argued that leaming objects help address a number of obstacles secondary schoolteachers face with respect to using technology including not having enough time, difficulties in leaming new software, creat ing effective integration strat egies, and accessibility (e.g. Agost inho, Bennett, Lockyer, \& Harper, 2004; Duval, Hodgins, Rehak, \& Robson, 2004; Gadanidis, Ga danidis, \& Schindler, 2003; Kay\& Knaack, 2007c; Rehak \& Mason, 2003). In addition, comprehensive,

Material published as part of this publication, either on-line or in print, is copyrighted by the Informing Science Institute. Permission to make digital or paper copy of part or all of these works for personal or classroomuse is granted without fee provided that the copies are not made or distributed for profit or commercial advantage AND that copies 1 ) bear this notice in full and 2) give the full citation on the first page. It is permissible to abstract these works solong as credit is given. To copy in all other cases or to republish or to post on a serveror to redistribute to lists requires specific permission and payment of a fee. Contact Publisher@.InformingScience.org to request redistribution permission. theoretically-based, reliable, and valid evaluation tools for assessing learning objects are scarce (Kay\& Knaack, in press). The purpose of this study was to examine the impact of learning objects in secondary school mathematics classrooms by using a comprehensive set of measures to assess teaching strategies, teacher attitudes, student attitudes, and learning performance. 


\section{Literature Review}

\section{Overview}

Until recently, learning objects were solely used in higher education; consequently the majority of research has taken place in this domain (Haughey \& Muirhead, 2005; Kay \& Knaack, in press). Increased use of leaming objects in the K-12 domain (e.g., Brush \& Saye, 2001; Clarke \& Bowe, 2006a, 2006b; Kay \& Knaack, 2005; Liu \& Bera, 2005; Lopez-Morteo \& Lopez, 2007; Nurmi \& Jaakkola, 2006) demands that the focus of investigation shift, at least in part, to the needs of middle and secondary school students. The current literature review will focus on three key areas: the potential of learning objects as an effective educational tool in secondary school classrooms, the proposed pedagogical benefits of learning objects, and research on the use of learning objects in K-12 mathematics classrooms to date.

\section{Potential for Using Learning Objects in Secondary School}

Without doubt, efforts to increase the use oftechnology in K-12 classrooms have been substantial in the past 10 years (Compt on \& Harwood, 2003; McRobbie, Ginns, \& Stein, 2000; Plante \& Beattie, 2004; US Department of Education, National Center for Education Statistics, 2002). In spite of this push, a number of researchers have argued that technology has had a minor and even negative impact on student learning (e.g., Cuban, 2001; Roberston, 2003; Russell, Bebell, O'Dwyer, \& O'Connor, 2003; Waxman, Connell, \& Gray, 2002). Part of the problem stems from a considerable list of obstacles that have prevented successful implementation.

Educators face a number of challenges when attempting to use technology in their classrooms including the amount of time required (Eifler, Greene, \& Carroll, 2001; Wepner, Ziomek, \& Tao, 2003), having to work with limited technological skills (Eifler et al., 2001; Strudler, Archambault, Bendixen, Anderson, \& Weiss, 2003; Thompson, Schmidt, \& Davis, 2003), fear of technology (Bullock, 2004; Doering, Hughes, \& Huffman., 2003), difficulty in understanding how to integrate technology into teaching (Cuban, 2001), and insufficient access (Bartlett, 2002; Brush et al., 2003; Russell et al., 2003).

Learning objects offer several promising solutions to the challenges that everyday teachers face with respect to using technology. First and foremost, leaming objects are easy to use. Teachers, even those who have limited computer-based skills, do not need to devote considerable blocks of time toward understanding how to use these straight forward tools (Gadanidis, et al., 2003; Kay \& Knaack, 2007c). Second, good learning objects have well defined objectives and a clear narrow focus making it easier to develop effective lesson plans and integration strat egies (Kay \& Knaack, $2007 \mathrm{c}$ ). Third, learning objects are readily accessible over the Internet. Given that over $90 \%$ of all public schools in North America and Europe now have access to the Internet (and therefore learning objects) with most having high-speed broadband connections (Compton \& Harwood, 2003; McRobbie et al., 2000; Plante \& Beattie, 2004; US Department of Education, National Center for Education Statistics, 2002), teachers need not worry about soft ware accessibility. Finally, reusability permits learning objects to be useful for a large audience, particularly when the objects are placed in well organized, searchable databases (e.g., Agostinho et al., 2004; Duval, Hodgins, Rehak \& Mason, 2004).

In summary, the accessibility and straight forward design of reusable, concept-focussed learning objects help address a number of obstacles teacher face with respect to using technology including time, difficulties in learning new software, integration strategies, and accessibility. 


\section{Pedagogical Benefits of Learning Objects}

A number of researchers have argued that learning objects, if carefully selected, have a considerable potentialto aid student leaming (Akpinar \& Bal, 2006; Liu \& Bera, 2005; Nurmi \& Jaakkola, 2006; Reimer \& Moyer, 2005). It is hypothesized that effective learning objects (a) require students to construct and manipulate information (Akpinar \& Bal, 2006; Baser, 2005; Nurmi \& Jaakkola, 2006), (b) provide rich feedback and interactive illustrations (Akpinar \& Bal, 2006), (c) help students understand abstract ideas with concrete representations (Akpinar \& Bal, 2006; Reimer \& Moyer, 2005) and (d) support key student weaknesses like limited working memory, difficulty in retrieving long term memory, and ineffective cognit ive strat egies (Liu \& Bera, 2005).

In addition, it is emphasized that instructional strat egies supporting the use of learning objects are critical for success, regardless of the quality of the learning object selected (Akpinar \& Bal, 2006; Clarke \& Bowe, 2006a; Nurmi \& Jaakkola, 2006; Reimer \& Moyer, 2005). A judicious mix of instruction, exploration, practice, and reflections is ideal (Nurmi \& Jaakkola, 2006). To date, the above list of hypotheses and speculations about the effective use of learning objects remain largely untested, particularly in the secondary school classroom.

\section{Impact of Learning Objects in Mathematics}

An extensive review of leaming objects articles in the past 10 years revealed 10 studies looking at the use of mathematics-based learning objects (Bower, 2005; Clarke \& Bowe, 2006a, 2006b; Gadanidis et al., 2003; Kay \& Knaack, 2007c; Kong \& Kwok, 2005; Lim, Lee, \& Richards, 2006; Nurmi \& Jaakkola, 2006; Reimer \& Moyer, 2005. It is worth noting that, aside from Gadanidis et al. (2003), these studies go back no further than 2005, indicating that research in this domain is are relatively new.

\section{Context}

While the 10 studies reviewed for this paper focussed on mathematics, the context of use varied widely with respect to grade level, time spent using learning objects, number of objects evaluated, and implementation strat egies. In terms of grade level, four studies looked at elementary school students (Bower, 2005; Clarke \& Bowe, 2006a, 2006b; Reimer \& Moyer, 2005), three studies investigated middle school students (Bower, 2005; Kong \& Kwok, 2005; Nurmi \& Jaakkola, 2006), two studies examined high school students (Kay \& Knaack, 2007c; Lopez-Morteo \& Lopez, 2007), and two studies focussed on higher education students (Gadanidis et al., 2003; Lim et al., 2006). T ime spent using learning objects, varied from 40 to 60 minutes (Akinpar \& Bal, 2006; Kay \& Knaack, 2007c; Nurmi \& Jaakkola, 2006) to several weeks (Clarke \& Bowe, 2006a, 2006b; Liu \& Bera, 2005; Reimer \& Moyer, 2005). Regarding the number of learning objects evaluated, half of the papers focussed on a single learning object, and half looked at multiple learning objects (Clarke \& Bowe, 2006a, 2006b; Kay \& Knaack, 2007c; Nurmi \& Jaakkola, 2006; Reimer \& Moyer, 2005). Finally, with implementation strategies, some teachers played a facilitat ing role, allowing students to explore the leaming object on their own (Kay \& Knnack, 2007c; Kong \& Kwok, 2005; Nurmi \& Jaakola, 2006), while otherteachers reported the use of multipleteaching techniques such as large group discussion, guiding worksheets, collaborat ive learning, and writing reflective comments (Clarke \& Bowe, 2006a; 2006b; Lim et al., 2006).

\section{Teacher perspective}

Only four studies looked at teacher att itudes toward the use of learning objects in the mathematics classroom (Clarke \& Bowe, 2006a; 2006b; Gadanidis et al., 2003; Kay \& Knaack, 2007c). Based largely on qualitative data collection methods, teachers valued several characteristics of leaming objects: the immediate feedback provided, the ability to replay and redo tasks for both enjoyment 
and mastery, and the motivational impact. Kay and Knaack (2007c) added quantitative evidence suggesting that pre-service teachers felt learning objects benefited student learning.

\section{Student perspective}

Seven studies looked at student attitudes toward learning objects. Mathematics students reported liking learning objects because they (a) were fun and enjoyable, (b) were easy to control with respect to the pace of learning, (c) provided timely feedback, (d) were easy to use, (e) consisted of a number multimedia tools, and (f) helped with learning (Clarke \& Bowe, 2006a, 2006b; Kay \& Knaack, 2007c; Lim et al., 2006; Lopez-Morteo \& Lopez, 2007; Nurmi \& Jaakkola, 2006; Reimer \& Moyer, 2005). Lim et al. (2006) and Nurmi and Jaakkola, (2006) added that the acceptance of learning objects was somewhat dependent on the kind of learning object used. Students in these studies favoured interactive, constructive learning objects over the "electronic" textbook prototype. Kay and Knack (2007c) offered quantitative evidence that students were moderately, but not exceedingly, positive about using mathematics-based learning objects.

\section{Student performance}

Four studies looked at learning performance after students used math-based learning objects, but none were done at the secondary school level (Bower, 2005; Kong \& Kwok, 2005; Nurmi \& Jaakkola, 2006; Reimer \& Moyer, 2005). In all four studies, element ary and middle school students who used learning objects showed significant improvement on various performance measures. Several cont extual details, though, are worth noting.

Nurmi and Jaakkola (2006) noted that learning performance was dependent on the type of learning object and how it was used. Students working with drill and practice learning objects were more focussed on compet ing with their peers than on learning. Students involved in a mixed learning object / lab-based lesson, performed significantly better than in other learning scenarios. In addition, Bower (2005) observed that students' performance improved when they received feedback comparing their personal performance to their peers.

\section{Purpose}

The purpose of this study was to examine the use of leaming objects in the secondary school mathematics classroom from the perspective of both teachers and students.

\section{Method}

\section{Overview}

This paper reviewed 10 articles looking at the use of learning objects in mathematics classrooms, although just two papers focussed on secondary schools. While half of the papers used mixed data collection methods, a number of issues need to be addressed to improve the investigation of learning objects.

First, eight out of ten studies used a qualitative approach to data collection that relied heavily on descriptive data and anecdotal reports to assess the merits of learning objects. The reliability and validity of these informal qualitative observations are questionable, as is relying on only one data source.

Second, limited information is provided on teacher att itudes toward learning objects. Only four studies examined teacher perspectives' on the actual use of leaming objects (Clarke \& Bowe, 2006a, 2006b; Kay \& Knaack, 2007c), however three of those studies reported "general impressions" of relatively small samples. 
Third, sample populations tested in K-12 studies are small and weakly described making it challenging to extend any conclusions to a larger population. Only two studies (Bower, 2005; Kay \& Knaack, 2007c) examined more than 100 students and average sample size was 70 students.

Fourth, triangulation of data collection is somewhat limited with only one study using more than two data collection procedures (Reimer \& Moyer, 2005). In addition, no researchers looked at student attitude, teacher attitude, and student performance simultaneously.

Finally, while most evaluation studies reported that students benefited from using learning objects, the evidence is based on assessment tools with no validity or reliability. Only two studies offered reliability estimates (Kay \& Knaack, 2007c; Kong \& Kwok, 2005) and one study, validity data (Kay \& Knaack, in press, 2007 c). The lack of reliability and validity of evaluation tools compromises the accuracy of results presented to date.

In summary, previous methods used to evaluate learning objects are limited with respect to collecting multiple data sources, evaluating teacher perspectives, acquiring an adequate sample size, and providing estimat es of reliability, and validity.

In order to address the key methodological challenges, the following steps were taken:

1. a large, diverse, sample was used;

2. reliability and valid surveys were used ;

3. formal statistics were used where applicable;

4. both qualitative and quant it at ive data were collected;

5. both teacher and student perspectives were assessed;

6. a measure of student performance was included; and

7. a number of learning objects were tested.

\section{Sample}

\section{Teachers}

The teacher sample consisted of 11 teachers ( 5 males, 6 females) and 20 classrooms (a number of teachers used learning objects more than once). T eaching experience ranged from 2 to 27 years with a mean of $9.3(S D=9.8)$. A majority of the teachers rated their ability to use computers as strong or very strong $(n=9)$ and their at titude toward using computers as positive or very positive $(n=10)$. In spite of the high computer ability and positive attitudes, only two of the teachers used computers in their classrooms more than once a month.

\section{Students}

The student sample consisted of 298 secondary school students (161 males, 137 females), 11 to 22 years of age $(M=16.3, S D=1.2)$. The population base spanned three separate boards of education, 9 secondary schools, and 20 different classrooms. The students were selected through convenience sampling and had to obtain signed parental permission to participate.

\section{Learning objects}

Teachers were permitted to select any learning object they deemed appropriate for their curriculum. As a starting point, they were introduced to a wide range of learning objects located at the LORDEC website (http://www.education.uoit.ca/lordec/collections.html). Seventy percent of the teachers selected learning objects from the LORDEC repository - the remaining teachers reported that they used Google. A total of 13 unique learning objects were selected (see

http://faculty.uoit.ca/kay/papers/Math LO.html for links to of all the learning objects used). Key topics covered included algebra, coordinate planes, congruent triangles, equation of a line, integer 
addition and multiplication, slope of a line, proportional relationships, parabolic transformations, investigating triangle centres, exponential functions, and the binomial distribution.

\section{Procedure}

Teachers from three boards of education were emailed by an educational coordinat or and informed of the learning object study. Participation was voluntary and a subject could withdraw from the study at any time. Each teacher received a half day oftraining in November on how to choose, use, and assess learning objects (see http://www.education.uoit.ca/lordec/lo use.html for more details on the training provided). They were then asked to use at least one learning object in their classrooms by April of the following year. Email support was available throughout the duration ofthe study. All students in a given teacher's class used the learning object that the teacher selected. However, only those students with signed parental permission forms were permitted to fill in an anonymous, online survey about their use of the learning object. In addition, students completed a pre- and post-test based on the content of the leaming object.

All teachers in this study used learning objects in a lab setting. In orderto simulate real secondary school environment as much as possible, teachers were given full control over the learning object they selected, the purpose for using the learning object, how long the learning object was used, teaching strategies for using the leaming objects, and the design of the pre- and post-tests.

\section{Data Sources}

\section{Teacher use}

Teachers were asked (a) how much preparation was involved when using learning objects (e.g., how long it took them to find and integrate learning objects into their classroom), (b) their purpose for using the learning object (e.g., motivate students, teach a new concept, review, supplementing a lesson), (c) strat egies they used to int egrate learning objects (e.g., demonstration, providing a set of guiding questions, let student explore, discussion after leaming object) and (d) how long the learning object was used in their classroom.

\section{Teacher survey}

After using a learning object, each teacher completed the Learning Object Evaluation Scale for Teachers (LOES-T) to det ermine their perception of (a) how much their students learned (learning construct), (b) the quality of the learning object (quality construct), and (c) how much their students were engaged with the learning object (engagement construct). Dat a from the LOES-T showed low to moderate reliability ( 0.63 for leaming construct, 0.69 for learning object quality construct, 0.84 for engagement construct), and good construct validity using a principal components factor analysis. See Kay and Knaack (2007d) for a detailed of the teacher-based learning object scale.

\section{Teacher comments}

Finally, teachers were asked to comment on the overall impact that the learning object had on learning(see Q9, Appendix A).

\section{Student survey}

After using a learning object, students completed the Learning Object Evaluation Scale for Students (LOES-S) in Appendix B to determine their perception of (a) how much they learned (learning construct), the quality of the learning object (quality construct), how much they were engaged with the learning object (engagement construct). The constructs selected were based on 
a thorough review of the literature (Kay \& Knaack, 2007a, 2007b). The scale showed good reliability ( 0.78 to 0.89 ), face validity, construct validity, convergent validity, and predictive validity (see Kay \& Knaack, in press).

\section{Student comments}

Students were asked to comment on what they liked and disliked about the learning object (Appendix $\mathrm{B}$ - questions 13 and 14). These qualitative items were analysed according to the coding scheme provided in Table 1. This coding scheme (Kay \& Knaack, 2007) was used to categorize 447 student comments. Each comment was then rated on a five-point Likert scale $(-2=$ very neg-

Table 1. Coding Scheme to $\mathrm{C}$ ate gorize $\mathrm{Student} \mathrm{Commen}$ ts about Learning $\mathrm{O}$ bje cts

\begin{tabular}{|c|c|}
\hline Le a ming $\mathrm{C}$ ate gories & Criteria \\
\hline Learn & $\begin{array}{l}\text { Student comments about a specific or general learning/teaching } \\
\text { issue involved in using the LO }\end{array}$ \\
\hline Visual & $\begin{array}{l}\text { The student mention as visual feat ure of the LO that } \\
\text { helped/inhibited their learning }\end{array}$ \\
\hline \multicolumn{2}{|c|}{ En gagement $\mathrm{C}$ ategories } \\
\hline Challenge & $\begin{array}{l}\text { Refers to the ease/difficulty of the concepts being covered. Basi- } \\
\text { cally whetherthe content level of the LO matched the student's } \\
\text { cognitive level/understanding. } \\
\text { Code "it was easy" in here, but not "it was easy to use" }\end{array}$ \\
\hline Compare & Student compares LO to another method of learning \\
\hline Engage & $\begin{array}{l}\text { Student refers to program as being OR not being } \\
\text { fun/enjoyable/engaging/interesting }\end{array}$ \\
\hline Interactive & Student refers to some int eractive part feature of the LO \\
\hline Technology & $\begin{array}{l}\text { The student mention a technological issue with respect to using the } \\
\text { LO }\end{array}$ \\
\hline \multicolumn{2}{|l|}{ Quality Cate gories } \\
\hline Animate & Refers to quality of animations /moving pictures \\
\hline Audio & Refers to some audio/sound aspect of the learning object \\
\hline Easy & $\begin{array}{l}\text { Refers to clarity of instructions or how easy/hard the LO was to } \\
\text { use. It does not refer to how easy/hard the concept was to learn. }\end{array}$ \\
\hline Graphics & Refers to static picture or look of the program (e.g., colours) \\
\hline Help & $\begin{array}{l}\text { Refers specifically to help/hints/instructions/feedback provided by } \\
\text { the LO }\end{array}$ \\
\hline Control & Refers to student control of choice/pace in using the LO \\
\hline Organization/Design & Refers to quality of organization/design orthe LO \\
\hline Text & Refers to quality/amount of text in LO \\
\hline Theme & Refers to overall/general theme or CONTENT of LO \\
\hline
\end{tabular}


ative, $-1=$ negative, $0=$ neutral, $1=$ positive, $2=$ very positive). Two raters assessed all comments made by students based on category and rat ing value. Comments where cat egories or ratings were not exactly the same were shared and reviewed a second time by each rater. Using this approach, an inter-rater reliability of $99 \%$ was attained for categories and $100 \%$ for the rat ing values.

Note that the total impact of any one category was determined by multiplying the mean rating by the total number of students who made a comment. For example, from Table 4, the impact of visual supports on learning was calculated by multiplying the mean which was 1.00 by the number of student who commented about visual supports (24) for a total of 24.0.

\section{Student performance}

Students completed a pre-test and post-test created by each teacher based on the content of the learning object used in class. Questions for pre- and post-test were identical in form, but differed in the raw numbers used. The type of questions asked varied according to the goal of the specific learning objects. Some tests focussed primarily on factual knowledge while others assess higher order thinking focussing on "what-if" scenarios. The measure was used to determine student performance. Because of the wide range of learning objects used, it was not possible to assess the validity of this test data.

\section{Key Questions \& Data Analysis}

In order to examine the impact of learning objects on secondary school students, the following questions were addressed in the data analysis:

1. How do teachers use learning objects in their classrooms? (descriptive analysis of teacher use que stions);

2. How do teachers rate learning, quality, and engagement of learning objects? (descriptive analysis of teacher survey - LOES-T);

3. What was the overall impact of learning objects according to teachers? (analysis of qualitative teacher comments);

4. How do students rate learning, quality, and engagement of learning objects? (descriptive analysis of student survey - LOES-S);

5. What do students like and dislike most about learning objects? (qualitative analysis of student comments);

6. How do teacher ratings of learning objects compare with student rat ings? (correlation among learning, quality, and engagement constructs) and

7. How do learning objects affect student performance? (t-test comparing pre and post scores); and

8. How does teacher use of learning objects affect performance? (correlations among preparation, purpose, teaching strategies, time used, and student performance scores) 


\section{Results}

\section{Use of Learning Objects}

\section{Finding a learning object}

Fifty percent $(n=10)$ of the teachers reported that finding a suitable learning object took them less than 30 minutes. Thirty percent $(n=6)$ took 30 to 60 minutes to find an appropriate learning object. The remaining $20 \%(n=4)$ took over an hour to finding the learning object they wanted to use in their class.

\section{Preparing a learning object lesson}

With respect to preparation for using the learning object in class, $5 \%$ of the teachers $(n=1)$ spent little or no time, $40 \%(n=8)$ spent less than 30 minutes, $25 \%(n=5)$ spent 30 to 60 minutes, and the remaining $30 \%(n=6)$ spent over an hour.

\section{Using a learning object}

On average, teachers used learning objects for 37.1 minutes (S.D. 17.0); however there was considerable variability (15 to 70 minutes). Students worked on their own on computers in a majority of classrooms $(85 \%, n=17)$, with cooperative learning chosen only $15 \%$ of the time.

\section{Reason for using a learning object}

The top four reasons cited by teachers for using learning objects were to provide another way of looking at a concept $(75 \%, n=15)$, review a previous concept $(45 \%, n=9)$, explore a new concept before a lesson $(40 \%, n=8)$, and motivate students about a topic $(35 \%, n=7)$. T eachers rarely or never used learning objects to teach a new concept, explore a new concept aft er a formal lesson, or for homework $(4 \%, n=2)$.

\section{Strategies for using learning objects}

Teachers in this study typically provided a brief introduction to a learning object $(55 \%, \mathrm{n}=11)$ or let the students start exploring on their own $(45 \%, n=9)$. Only $20 \%(n=4)$ offered a formal demonstration of the learning object before the class used it. Forty-five percent of teachers $(n=9)$ prepared a formal handout or guiding que stions $(30 \%, n=6)$. Forty percent of teachers $(n=8)$ chose to have a class discussion about the learning object after it was used by students.

\section{Teacher Rating of Learning Objects}

\section{Learning}

The mean rating for impact learning was $10.8(S D=1.3)$ or 5.4 on a 7-point scale. This suggests that most teachers agreed somewhat that learning objects had a positive impact on student learning. Note that the range of learning construct scores was relatively narrow ( 8 to 13) (T able 2).

\section{Quality of Learning Object}

The mean rating of learning object quality was $16.0(S D=2.8)$ or 5.3 on a 7-point scale. Most teachers somewhat agreed or agreed that leaming objects were of good quality. The range of learning object quality scores was broader than that of the learning construct (11 to 20), but never dipped into negative rating (Table 2). 


\section{Engagement}

Teachers rated engagement of learning objects the highest of all constructs with a mean score of $16.9(S D=2.8)$ or 5.6 on a 7-point scale. A majority of teachers, then, felt students were engaged while using learning objects. The range of learning object engagement scores was relatively large compared to the learning and quality constructs (9 to 21) (Table 2).

Table 2. Teacher Rating of Learning, Quality, and En gagement for Learning $O$ bje cts

\begin{tabular}{lrccc}
\hline Scale & $\begin{array}{l}\text { No. } \\
\text { Items }\end{array}$ & $\begin{array}{c}\text { Possible } \\
\text { Range }\end{array}$ & $\begin{array}{c}\text { Actual Range } \\
\text { O bse rved }\end{array}$ & Me an (S.D) \\
\hline Learn & 2 & 2 to 14 & 8 to 13 & $10.8(1.3)$ \\
Quality & 3 & 3 to 21 & 11 to 20 & $16.0(2.8)$ \\
Engagement & 3 & 2 to 21 & 9 to 21 & $16.9(2.9)$ \\
\hline
\end{tabular}

\section{Teacher comments about learning objects}

Four themes emerged from the 24 comments that teachers made about the overall impact of the learning objects: overall learning, visual supports for leaming, engagement, and time.

With respect to overall learning, three teachers reported that the learning object was not as successful has they had hoped:

“Although the learning object did not improve as many students' initial understanding of equation solving as I had hoped, it was useful."

"[After the using the learning object] they still had great difficulty distinguishing between vertical and horizontal stretches and compressions.

However, six teachers commented that visual supports in the learning objects helped their students learn better:

"I felt that this particular learning object helped them gain a solid visual of what happens to a parabola as you change the numbers of the vertex form of a parabola."

"For many students, using the balance scale was an excellent visual representation of solving algebra problems."

Regarding engagement, five teachers noted that their students seemed to enjoy using the learning objects:

"Students enjoyed using the learning object and spending time on the computer in math class."

"I think students seemed to enjoy using it, especially the quiz."

Finally, four teachers mentioned that time was an issue, either in creating a good lesson plan with a learning object, saving time, booking the right time to use learning objects, or not having enough time.

"The learning object allowed me to take a much shorter time to teach to teach the concept after the students had been introduced to it in the learning object.

"I had only had one class prior to using the learning object to introduce the concept to the class because of problems at the school in terms of booking computer time." 


\section{Student Rating of Learning Objects}

\section{Learning}

Students rated leaming objects lower than teachers with respect to learning ( $M=15.65, S D=4.6)$ with a mean it em rating of 3.1 out of 5 (or 4.4 out of 7 ). Students were relatively neutral with respect to how much they felt the learning objects contributed to their learning. The range of scores was extensive ( 5 to 25 ) indicating that there was considerable variability with respect to whether students felt learning objects helped them learn (T able 3).

\section{Quality of learning objects}

Students rated the quality of learning objects higher than their learning value, although the mean item rat ing was still lower than that of the teachers. The mean item rating was 3.4 out of 5 (4.8 or out 7) indicated that most students somewhat agreed that the learning objects they used were of good quality. The range of learning object quality scores (4 to 20 ) was highly variable (Table 3 ).

\section{Engagement}

Ratings of leaming object engagement were moderate $(M=9.34, S . D .=2.8)$ with a mean item rating of 3.1 out or 5 (or 4.4 out of 7 ). In other words, as was the case with the learning construct, students were neutral about engagement value of the learning objects they used. High variability among student engagement ratings is supported by the wide range of scores reported ( 3 to 15 ).

Table 3. Description of Stu dent Le arning O bject Evalu ation S cales (LO ES-S)

\begin{tabular}{lrccc}
\hline Scale & $\begin{array}{l}\text { No. } \\
\text { Items }\end{array}$ & Possible Range & $\begin{array}{c}\text { Actual Range } \\
\text { Observed }\end{array}$ & Mean (S.D) \\
\hline Learn & 5 & 5 to 25 & 5 to 25 & $15.4(4.3)$ \\
Quality & 4 & 4 to 20 & 4 to 20 & $13.5(3.4)$ \\
Engagement & 3 & 3 to 15 & 3 to 15 & $9.1(2.6)$ \\
\hline
\end{tabular}

\section{Student comments about learning objects}

Student comments are summarized in T able 4. With respect to learning, the visual support that a learning object offered toward learning was rated the highest, whereas overall learning and the pedagogical challenge of the learning object were rated quite low. In other words, many students liked the visual affordances of learning objects, however quite a few felt the learning object did not support learning or was not challenging enough.

With respect to rating the quality of learning objects, ease of use was the highest rated feat ure. On the other hand, the quality of help and having excessive amounts of text were rated the lowest.

Finally, regarding engagement, interactivity, and comparison with other methods of teaching were rated the highest. A number of the students liked the interactive qualities of learning objects and felt they were an improvement over other teaching strategies. 
Table 4. Summary of Stu dent Commen ts abou t Learning $O$ bje cts

\begin{tabular}{lcccc}
\hline Category & Me an & S.D & n & $\begin{array}{c}\text { Total Effect } \\
\text { Me an * n }\end{array}$ \\
\hline Learning & & & & \\
$\quad$ Visual Supports & 1.00 & 0.00 & 24 & 24.0 \\
$\quad$ Challenge & -0.46 & 1.02 & 52 & -24.0 \\
$\quad$ Overall Learning & -0.37 & 1.11 & 75 & -28.0 \\
Quality & & & & \\
Easy & 0.88 & 0.80 & 24 & 21.0 \\
Control & 0.71 & 0.76 & 7 & 5.0 \\
$\quad$ Animation & 1.00 & 0.00 & 2 & 2.0 \\
Graphics & -0.14 & 1.25 & 29 & -4.0 \\
Theme & -0.43 & 1.22 & 14 & -6.0 \\
Organization & -0.81 & 0.98 & 16 & -13.0 \\
Help & -0.86 & 0.75 & 28 & -24.0 \\
T ext & -1.19 & 0.40 & 21 & -25.0 \\
Engagement & & & & \\
Interactivity & 0.90 & 0.44 & 21 & 19.0 \\
Compare with other method & 0.67 & 0.76 & 24 & 16.0 \\
Liking Technology & 0.50 & 0.91 & 12 & 6.0 \\
Engagement / Motivation & -0.04 & 1.18 & 50 & -2.0 \\
\hline
\end{tabular}

\section{Student Performance}

Overall, student performance scores increased by an average of $7.6 \%$ from $56.4 \%$ to $64.0 \%$. This change was significant $(t=-3.85, d f=123, p<.001)$. The effect size (based on Cohen's d) of 0.29 is considered a small effect according to Thalheimer \& Cook (2002). Note that the average student performance score by class varied considerably ranging from a $4.2 \%$ decrease to a $27.1 \%$ increase.

\section{Teacher Use and Student Performance}

Four areas of teacher use were examined with respect to student performance: preparation, purpose, strategies for teaching, and the amount of time a learning object was used. With respect to preparation, time spent finding a learning object was inversely correlated with student performance $(r=-0.34, p<.001)$. In other words, the more time a teacher spent looking for a leaming object, the less successful the learning object was in terms of student performance. Planning time was strongly correlated with student performance $(r=0.69, p<.001)$.

Regarding the main purpose or objective for using a learning object, introducing a new concept, then following up with a formal lesson $(r=0.68, p<.001)$ and reviewing previously learned concepts $(r=0.36, p<.001)$ were significantly correlated with student performance. However, us- 
ing a learning object to motivate students and give them another way of looking at a concept was negatively correlated with student performance $(r=-0.31, p<.001)$.

In terms of teaching strategies used with learning objects, positive correlations with student performance were seen when a worksheet and guiding questions were provided $(r=0.57, p<.001)$ and when students were encouraged to explore on their own $(r=0.29, p<.005)$. On the other hand, negative correlations were observed when a brief demonstration of the learning object was given $(r=-0.41, p<.001)$ or when the learning object was discussed after the student had used it $(r=-0.43, p<.001)$.

Finally, the amount of time that students used a leaming object in class was negatively correlated with student performance $(r=-0.28, p<.005)$.

\section{Discussion}

The purpose of this study was to investigate the impact of learning objects in secondary school mathematics classrooms. Evidence gathered to evaluate effectiveness included a description of teacher use, teacher att it udes, teacher comments, student att it udes, student comments, and student performance. Each of these sources of evidence will be disc ussed.

\section{Teacher Use}

\section{Preparation}

Previous research has not been done looking at how teachers find learning objects and prepare to use them in the science classroom. This study provides new information in this area. Searching for and planning to use a learning object does not take an inordinate amount of time - on average, a half hour for each activity. It is interesting to note that planningtime was strongly correlated with increases in student performance. While a few teachers commented that time was a concern, it is clear that this time investment is worthwhile.

Paradoxically, time spent searching for learning objects was inversely related to student performance. It is possible that teachers who took longer to search for learning objects were simply unable to find one that fit their needs. They may have settled for a lower quality learning object simply because they ran out of time. Conversely, teachers who found learning objects quickly may have been impressed by a high quality learning object early on in the search process.

\section{Purpose for using learning object}

Three quarters of the teachers used learning objects to provide another way of looking at a concept; however this approach resulted in significantly lower student performance. It is unclear why students faltered with this approach. Perhaps the "other" way of leaming a concept was viewed as unnecessary and maybe confusing. Almost half the teachers used learning objects for review, a goal that correlated significantly with gains in student performance. Students appear to have reacted more positively when a deliberate review was planned, as opposed to a less focussed lesson that simply looked at a current concept in an alternative way. Students may also have been more motivated and focussed during a review because a formal test was imminent.

Four out often teachers chose to use learning objects to introduce a new concept before a formal lesson, an objective that was strongly correlated with improved student performance. This result is partially confounded by the fact that a formal lesson was used in conjunction with a learning object. It is impossible to determine the relative contribution of the learning object to final performance. That said, using this tool to lead into more formal instruction works very well. 


\section{Teaching strategies}

The number one strat egy for using learning objects, namely providing a brief introduction, was negatively correlated with student performance. At first glance, this finding seems counter intuitive. It would be expected that students, even in the worst case scenario, would react in a neutral manner to a brief introduction, simply because it is "brief". Then again, learning objects that truly require and introduction may be of lower quality and harder to use.

Another strategy that was used relatively often, but that resulted in lower student performance, was the practice of having a class discussion after students used the learning object. Again, this finding is opposite to what one would expect. One explanation might be that class discussion was used when the use of learning objects did not go smoothly, when there were problems, and perhaps when confusion was experienced by students. A more detailed description of the discussion is required to fully understand this result.

A strategy that was significantly correlated with learning was the inclusion of a worksheet with guiding que stions. This kind of support may have focussed students to concentrate on the key concepts at hand, thereby resulting in increased understanding oftested items.

Finally, students clearly prefer to explore learning objects on their own, a strategy that resulted in increased student performance. Learning objects that permit students to simply "jump in" may be better designed in terms of usability, particularly if they are supplemented with guiding worksheets.

\section{Teacher Ratings (Learning, Quality, and Engagement)}

There is no question that the vast majority of teachers believed that the learning objects they selected were good quality, engaging tools that supported learning. Ratings of these constructs were fairly high. On the one hand, it may be obvious that teachers would give high ratings, since they selected the leaming objects in the first place. On the other hand, teachers rated these learning objects after they watched them being used by students in their classroom. In addition, they had no personal stake in approving these tools, and three teachers felt open enough to acknowledge that learning objects had not fully met their expectations. Positive reaction from teachers in this study is consistent with results reported in previous research (Clarke \& Bowe, 2006a; 2006b; Gadanidis et al., 2003; Kay \& Knaack, 2007d).

\section{Teacher Comments}

With respect to learning, teacher comments supported both survey and learning performance results, however a few teachers were disappointed in the final impact. A number of teachers felt that the learning objects offered helpful visual supports and that the tool was engaging for students. In addition, leaming objects were thought to be engaging. These comments are consistent with observations made by previous researchers (Clarke \& Bowe, 2006a;2006b; Gadanidis et al., 2003; Kay \& Knaack, 2007d).

\section{Student Ratings (Learning, Quality, and Engagement)}

On average, students were neutral with respect to the learning, quality, and engagement impact of learning objects. These results are somewhat consistent with the modest enthusiasm expressed in the one other study that formally evaluated the use of math-based learning objects by secondary school students (Kay \& Knaack, 2007d). It is critical to note, though, that the range of scores was very broad for allthree constructs. For any given learning object, even when it was used by the same class, some students liked it a lot and others disliked it intensely. Leaming objects clearly do not suit every student's learning style. The challenge remaining is to identify the source and perhaps cause of individual differences. 
Finally, teachers rated leaming, quality, and engagement much higher than students. What mathematics teachers think is an effective, high quality, motivating teaching tool, may be perceived as neutral or barely acceptable by students. Teachers might be wise to test learning objects with a few representative students, before exposure to the whole class.

\section{Student Comments about Learning Objects}

Student comments offer insight into what students like and do not like about learning objects. Not surprisingly, students liked easy to use, interactive learning objects that provided good visual supports. They reacted negatively, though, to poor quality help and having to read excessive amounts of text. These reactions are similar to those made by students in previous studies (Clarke \& Bowe, 2006a; Clarke \& Bowe, 2006b; Kay \& Knaack, 2007d). Finally, it is interesting to note that even though students were relatively neutral about the learning objects they used, a noticeable number of students reported that using learning objects was an improvement over other teaching methods.

\section{Student Performance}

This is a first study on the impact of learning objects in secondary school mathematics classes with respect to leaming performance. The fact that learning performance increased is not surprising given the wealth of previous research that has reported similar results at other grade levels (Akpinar \& Bal, 2006; Baser, 2005; Liu \& Bera, 2005; Nurmi \& Jaakkola, 2006; Rieber, T zeng, $\&$ T ribble, 2004; Schoner, Buzza, Harrigan, \& Strampel, 2005; W indschitl \& Andre, 1998). However, the magnitude of the overall effect $(7.6 \%)$ was fairly small. It is important, though, to be cognisant of two other results. First, the variability in student performance among classrooms was considerable - from a drop of $4 \%$ to and increase of $27 \%$. So the more critical question is, "Why are learning objects successful in some classes, but ineffective in others?" The results of this study suggest that the answer, at least in part, is increased planning time, using learning objects for review or to introduce a new concept, and supplying guided handouts to focus students

\section{Implications for Education}

This study offers several practical observations and suggestions for using learning objects in secondary school mathematics classrooms. First, it is important to take sufficient time to prepare for lessons involving learning objects. Second, lessons should have a clear focus like introducing a new concept or reviewing previous concepts. Simply using a learning object as another way of looking at a concept may confuse students and have a detrimental effect. Third, a supporting handout with guided questions should improve student performance. Fourth, the effect of learning objects may vary greatly with in the same classroom. Accommodations could have to be made for students with different ability and interest levels. Finally, it might be wise to pre-test learning objects on a few students. Students and teachers differ considerably on what they see as high quality, engaging learning objects that promote learning. On average, students appear to have a more accurate sense of these qualities, at least when it comes to predict ing learning performance.

\section{Caveats and Future Research}

In this study, careful attention was directed toward collecting good quality data by sampling a large, relatively diverse population, establishing the reliability and validity of measures used, and using multiple data sources to establish triangulation. Nonetheless, several limitations exist which provide opport unities for fut ure researchers. First, the overall results saw inconsistencies between teacher att itudes, student attitudes, and student performance. More extensive qualitative 
data in the form of focus groups and/or interviews might shed further light one why these discrepancies exist and what role leaming objects have to play.

Second, more qualitative data is needed to understand how teacher goals and strategies influence student performance. A number of strong, significant correlations were observed, but it was challenging to int erpret what teachers were doing. For, example brief introductions to learning objects were negatively correlated with student performance. It is difficult to comprehend this unexpected finding without knowing the intended message of these introductory segments.

Finally, the impact of specific kinds of learning objects was not looked at. It is possible that certain cat egories of learning objects may have decidedly different impacts on learning. The wide variability in student performance among classes may be partially explained by teachers' goals and strategies, but the type of learning object used may also have an impact. Developing and evaluating a classification system for learning objects is an important next step in learning object research.

\section{References}

Agostinho, S., Bennett, S., Lockyear, L., \& Harper, B. (2004). Developing a learning object metadata application profile based on LOM suitable for the Australian higher education market. Australasian Journal of Educational Technology, 20(2), 191-208.

Akpinar, Y. \& Bal, V. (2006). Student tools supported by collaboratively authored tasks: The case of work learning unit. Journal of Interactive Learning Research, 17(2), 101-119.

Bartlett, A. (2002). Preparing preservice teachers to implement performance assessment and technology through electronic port folios. Action in Teacher Education, 24(1), 90-97.

Baser, M. (2005). Promoting conceptual change through active learning using open source software for physics simulations. Australasian Journal of Educational Technology, 22(3), 336-354.

Bower, M. (2005). Online assessment feedback: Competitive, individualistic, or...preferred form! Journal of Computers in Mathematics and Science Teaching, 24(2), 121-147.

Brush, T., Glazewski, K, Rutowski, K., Berg, K., Stromfors, C., Van-Nest, M., Stock, L., \& Sutton, J. (2003). Integrating technology in a field-bas ed teacher training program: The PT3@ASU project. Educational Technology, Research and Development, 51(1), 57-73.

Brush, T. \& Saye, J. (2001). The use of embedded scaffolds with hypermedia-supported student-centered learning. Journal of Educational Multimedia and Hypermedia, 10(4), 333-356.

Bullock, D. (2004). Moving from theory to practice: An examination of the factors that preservice teachers encounter as the attempt to gain experience teaching with technology during field placement experiences. Journal of Technology and Teacher Education. 12 (2), 211-237.

Clarke, O., \& Bowe, L. (2006a). The learning federation and the Victorian department of education and training trial of online curriculum content with Indigenous students. 1-14. Retrieved from http://www.thelearningfederation.edu.au/verve/ resources/tlf detvic indig trial mar06.pdf

Clarke, O., \& Bowe, L. (2006b). The learning federation and the Victorian department of education and training trial of online curriculum content with ESL students. 1-16. Retrieved from http://www.thelearningfederation.edu.au/verve/ resources/report esl final.pdf

Compton, V., \& Harwood, C. (2003). Enhancing technological practice: An assessment framework for technology education in New Zealand. International Journal of Technology and Design Education, 13(1), 1-26.

Cuban, L. (2001). Oversold and underused: Computers in the classroom. Cambridge, MA: Harvard University Press. 
Doering, A., Hughes, J., \& Huffman, D. (2003). Preservice teachers: Are we thinking with technology? Journal of Research on Technology in Education, 35(3), 342-361.

Duval, E., Hodgins, W., Rehak, D., \& Robson, R. (2004). Learning objects symposium special issue guest editorial. Journal of Educational Multimedia and Hypermedia, 13(4), 331-342.

Eiffer, K. Greene, T., \& Carroll, J. (2001). Walking the talk is tough: From a single technology course to infusion. The Educational Forum. 65(4), 366-375.

Gadanidis, G., Gadanidis, J., \& Schindler, K. (2003). Factors mediating the use of online applets in the lesson planning of pre-service mathematics teachers. Journal of Computers in Mathematics and Science Teaching, 22(4), 323-344.

Haughey, M., \& Muirhead, B. (2005). Evaluating learning objects for schools. E-Journal of Instructional Sciences and Technology, 8(1). Retrieved June 1, 2007 from http://www.usq.edu.au/electpub/eiist/docs/vol8 no1/fullpapers/eval learnobjects school.htm

Kay, R. H., \& Knaack, L. (in press). Assessing learning, quality and engagement in learning objects: The learning object evaluation scale for students (LOES-S). ETR\&D.

Kay, R. H., \& Knaack, L. (2005). Developing learning objects for secondary school students: A multicomponent model. Interdisciplinary Journal of Knowledge and Learning Objects, 1, 229-254. Retrieved from http://ijello.org/Volume1/v1p229-254Kay Knaack.pdf

Kay, R. H., \& Knaack, L. (2007a). A systematic evaluation of learning objects for secondary school students. Journal of Educational Technology Systems, 35(4), 411-448.

Kay, R. H., \& Knaack, L. (2007b). Evaluating the learning in learning objects. Open Learning, 22(1), 5-28.

Kay, R. H., \& Knaack, L. (2007c). Evaluating the use of learning objects for second ary school science. Journal of Computers in Mathematics and Science Teaching, 26(4), 261-289.

Kay, R. H., \& Knaack, L. (2007d). Teacher evaluation of learning objects in middle and secondary school classrooms. Manuscript submitted for publication. Retrieved Feb, 2008 from http://faculty.uoit.ca/kay/papers/LOES Teacher 2007.pdf.

Kong, S. C., \& Kwok, L. F. (2005). A cognitive tool for teaching the addition/subtraction of common fractions: A model of afford ances. Computers and Education, 45(2), 245-265.

Lim, C. P., Lee, S. L. \& Richards, C. (2006). Developing interactive learning objects for a computing mathematics models. International Journal on E-Learning, 5(2), 221-244.

Liu, M., \& Bera, S. (2005). An analysis of cognitive tool use patterns in a hypermedia learning environment. Educational Technology, Research and Development, 53(1), 5-21.

Lopez-Morteo, G., \& Lopez, G. (2007). Computer support for learning mathematics: A learning environment based on recreational learning objects. Computers and Education, 48(4), 618-641.

McRobbie, C. J., Ginns, I. S., \& Stein, S. J. (2000). Preservice primary teachers' thinking about technology and technology education. International Journal of Technology and Design Education, 10, 81-101.

Nurmi, S., \& Jaakkola, T. (2006). Effectiveness of learning objects in various instructional settings. Learning, Media, and Technology, 31(3), 233-247.

Plante, J., \& Beattie, D. (2004). Education, skills and learning - Research papers Connectivity and ICT integration in Canadian elementary and secondary schools: First results from the Information and Communications Technologies in Schools Survey, 2003-2004. Statistics Canada. Retrieved Aug 29, 2004 from http://www.schoolnet.ca/home/documents/Report EN.pdf

Rehak, D., \& Mason, R. (2003). Chapter 3: Keeping the learning in learning objects. Journal of Interactive Media in Education, 1. Retrieved July 1, 2005 from http://www-jime.open.ac.uk/2003/1/reuse-05.html

Reimer, K., \& Moyer, P. S. (2005). Third-graders learning about fractions using virtual manipulatives: A classroom study. Journal of Computers in Mathematics and Science Teaching, 24(1), 5-25. 
Rieber, L. P., Tzeng, S., \& Tribble, K. (2004). Discovery learning, repres entation, and explanation within a computer-based simulation: Finding the right mix. Learning and Instruction, 14(3), 307-323.

Robertson, H. (2003). Toward a theory of negativity: Teacher education and information and communications technology. Journal of Teacher Education, 54(4), 280-296.

Russell, M., Bebell, D., O’ Dwyer, L., \& O’Connor, K. (2003). Examining teacher technology use: Implications for preservice and inservice teacher preparation. Journal of Teacher Education, 54(4), 297-310.

Schoner, V., Buzza, D., Harrigan, K. \& Strampel, K.. (2005). Learning objects in use: 'Lite' assessment for fi eld studies. Journal of Online Learning and Teaching, 1(1), 1-18.

Strudler, N., Archambault, L., Bendixen, L., Anderson, D., \& Weiss, R. (2003). Project THREAD: Technology helping restructure educational access and delivery. Educational Technology Research and Development, 51(1), 39-54.

Thalheimer, W., \& Cook, S. (2002). How to calculate effect sizes from published research articles: A simplified methodology. Retrieved July 14, 2007 from http://work-learning.com/effect sizes.htm

Thompson, A. D., Schmidt, D. A., \& Davis, N. E. (2003). Technology collaboratives for simultaneous renewal in teacher education. Educational Technology Research and Development, 51(1), 73-89.

U.S. Department of Education, National Center for Education Statistics (2002). Internet access in U.S. public schools and classrooms: 1994-2002. Retrieved August 30, 2004 from http://nces.ed.gov/programs/digest/d02/tables/dt419.asp

Waxman, H. C., Connell, M. L., \& Gray, J. (2002). A quantitative synthesis of recent research on the effects of teaching and learning with technology on student outcomes. Naperville, IL: North Central Regional Laboratory.

Wepner, S. B., Ziomek, N., \& Tao L. (2003). Three teacher educators' perspectives about the shiffing responsibilities of infusing technology into the curriculum. Action in Teacher Education, 24(4), 53-63.

Windschitl, M., \& Andre, T. (1998). Using computer simulations to enhance conceptual change: The roles of constructivist instruction and student epistemological beliefs. Journal of Research in Science Teaching, 35(2), 145-160. 


\section{Appendix A - Learning Object Survey - Teachers}

\begin{tabular}{|c|c|c|c|c|c|c|c|}
\hline & $\begin{array}{c}\text { Strongly } \\
\text { Disagree } \\
1\end{array}$ & $\begin{array}{c}\text { Disagree } \\
2\end{array}$ & $\begin{array}{c}\text { Slightly } \\
\text { Disagree } \\
3\end{array}$ & $\begin{array}{c}\text { Neutral } \\
4\end{array}$ & $\begin{array}{l}\text { Slightly } \\
\text { Agree } \\
5\end{array}$ & $\begin{array}{l}\text { Agree } \\
6\end{array}$ & $\begin{array}{l}\text { Strongly } \\
\text { Agree } \\
7\end{array}$ \\
\hline \multicolumn{8}{|l|}{ Learning } \\
\hline $\begin{array}{l}\text { 1. The graphics and an- } \\
\text { imations from the } \\
\text { learning object helped } \\
\text { students learn. }\end{array}$ & 1 & 2 & 3 & 4 & 5 & 6 & 7 \\
\hline $\begin{array}{l}\text { 2. The students were } \\
\text { able to learn from the } \\
\text { learning object. }\end{array}$ & 1 & 2 & 3 & 4 & 5 & 6 & 7 \\
\hline \multicolumn{8}{|l|}{ Quality } \\
\hline $\begin{array}{l}\text { 3. The learning object } \\
\text { was easy for students } \\
\text { to use. }\end{array}$ & 1 & 2 & 3 & 4 & 5 & 6 & 7 \\
\hline $\begin{array}{l}\text { 4. The learning object } \\
\text { was easy to learn. }\end{array}$ & 1 & 2 & 3 & 4 & 5 & 6 & 7 \\
\hline $\begin{array}{l}\text { 5. The students found } \\
\text { the learning object in- } \\
\text { structions clear }\end{array}$ & 1 & 2 & 3 & 4 & 5 & 6 & 7 \\
\hline \multicolumn{8}{|l|}{ Engagement } \\
\hline $\begin{array}{l}\text { 6. The students liked } \\
\text { interacting with the } \\
\text { learning object. }\end{array}$ & 1 & 2 & 3 & 4 & 5 & 6 & 7 \\
\hline $\begin{array}{l}\text { 7. The students were on } \\
\text { task while using the } \\
\text { learning object. }\end{array}$ & 1 & 2 & 3 & 4 & 5 & 6 & 7 \\
\hline $\begin{array}{l}\text { 8. Students were moti- } \\
\text { vated while using the } \\
\text { learning object. }\end{array}$ & 1 & 2 & 3 & 4 & 5 & 6 & 7 \\
\hline
\end{tabular}

Overall Impact on Learning

9. What was the overall impact of the learning object on your lesson? 


\section{Appendix B - Learning Object Survey - Students}

\begin{tabular}{|c|c|c|c|c|c|}
\hline & $\begin{array}{c}\text { Strongly } \\
\text { Disagree } \\
1\end{array}$ & $\begin{array}{l}\text { Disagree } \\
\quad 2\end{array}$ & $\begin{array}{c}\text { Neutral } \\
3\end{array}$ & $\begin{array}{l}\text { Agree } \\
4\end{array}$ & $\begin{array}{c}\text { Strongly } \\
\text { Agree } \\
5\end{array}$ \\
\hline \multicolumn{6}{|l|}{ Learning } \\
\hline $\begin{array}{l}\text { 1. Working with the learning object helped me } \\
\text { learn. }\end{array}$ & 1 & 2 & 3 & 4 & 5 \\
\hline $\begin{array}{l}\text { 2. The feedback from the learning object helped } \\
\text { me learn. }\end{array}$ & 1 & 2 & 3 & 4 & 5 \\
\hline $\begin{array}{l}\text { 3. The graphics and animations from the learn- } \\
\text { ing object helped me learn. }\end{array}$ & 1 & 2 & 3 & 4 & 5 \\
\hline $\begin{array}{l}\text { 4. The learning object helped teach me a new } \\
\text { concept. }\end{array}$ & 1 & 2 & 3 & 4 & 5 \\
\hline 5. Overall, the learning object helped me leam. & 1 & 2 & 3 & 4 & 5 \\
\hline \multicolumn{6}{|l|}{ Quality } \\
\hline $\begin{array}{l}\text { 6. The help features in the learning object were } \\
\text { useful. }\end{array}$ & 1 & 2 & 3 & 4 & 5 \\
\hline $\begin{array}{l}\text { 7. The instructions in the learning object were } \\
\text { easy to follow. }\end{array}$ & 1 & 2 & 3 & 4 & 5 \\
\hline 8. The learning object was easy to use. & 1 & 2 & 3 & 4 & 5 \\
\hline 9. The learning object was well organized. & 1 & 2 & 3 & 4 & 5 \\
\hline Engagement & 1 & 2 & 3 & 4 & 5 \\
\hline $\begin{array}{l}\text { 10. I liked the overall theme of the leaming ob- } \\
\text { ject. }\end{array}$ & 1 & 2 & 3 & 4 & 5 \\
\hline 11. I found the learning object motivating. & 1 & 2 & 3 & 4 & 5 \\
\hline $\begin{array}{l}\text { 12. I would like to use the learning object } \\
\text { again. }\end{array}$ & 1 & 2 & 3 & 4 & 5 \\
\hline
\end{tabular}

13. What, if anything, did you LIKE about the learning object?

14. What, if anything, did you NOT LIKE about the learning object? 


\section{Biographies}

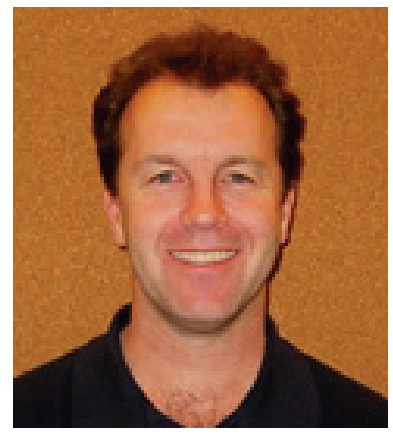

Robin Kay, Ph.D. is an Associate Professor in the Faculty of Education at the University of Ontario Inst it ute of Technology. He has published over 40 articles in the area of computers in education, presented numerous papers at 10 international conferences, refereed three prominent computer education journals, and taught computers, mathematics, and technology for over 18 years. Current projects include research on laptop use in teacher education, discussion board use, electronic evaluation of teacher education programs, and factors that influence how students learn with technology.

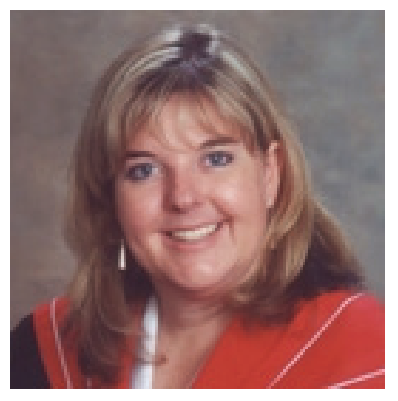

Liesel Knaack, Ph.D. is an Associate Professor in the Faculty of Education at the University of Ontario Institute of Technology. Her research interests are in the areas of design, development and evaluation of learning objects, effective integration of computers in the curricula, instructional design of digital learning environments and the process of change in implementing technology use at institutions of higher education. Current projects include laptop use in preservice education programs, online discussions and digital performance appraisals. 